\title{
CORTICAL BRANCHES OF THE MIDDLE CEREBRAL ARTERY IN EUROPEAN BADGER (MELES MELES)
}

\author{
Benedykt Skoczylas, Witold Brudnicki, Krzysztof Kirkiłło-Stacewicz*, Włodzimierz Nowicki, Jan Wach \\ UTP University of Science and Technology, Faculty of Animal Breeding and Biology, Department of Physiology, Zoophysiotherapy and \\ Animal Breeding, Mazowiecka 28, 85-084 Bydgoszcz, Poland \\ *Corresponding author, E-mail: krzysztof.stacewicz@o2.pl
}

\begin{abstract}
The pattern and variation of the cortical branches of the middle cerebral artery in European badgerwere studied for 64 cerebral hemispheres. It was found that the artery bifurcates into splits into ten permanent branches. Two olfactory arteries supply the area of the brain situated on the border between the old and the new cortex. The other eight branches get divided into three branches heading for the frontal region, two branches - to the parietal region and three temporal branches which supply only the new cortex. The frontal, parietal and temporal branches descended independently from the main trunk of the middle cerebral artery or formed a common trunk first. Common trunks for respective groups of branches have been described as the rostral, dorsal and caudal middle cerebral artery. The rostral olfactory artery in 6.3\% of the cases investigated was an independent branch from the rostral cerebral artery.
\end{abstract}

Key words: arteries; brain; European badger

\section{Introduction}

The first information on the anatomy of the middle cerebral artery in various mammals is given by Hofmann (1). In the applicable literature ob the blood supply to the brain one can find papers discussing the pattern of descent of the middle cerebral artery and its division into cortical branches. The issues were described for domestic pig by Walinczus (2) who covered the range and the pattern of blood supply to respective cerebrum

Received:28March 2018

Accepted for publication: 28 April 2020 regions. The pattern of the middle cerebral artery and its cortical branches in cat were described by Chadzypanagiotis (3); the author provides the nomenclature on respective cortical branches of that artery.

Systematic descriptions of the division and the pattern of the cortical branches of the middle cerebral artery in some Carnivora species are provided by Wiland (4), in wild boar - by Skoczylas \& Wiland (5).

Over the recent years there have appeared numerous papers on the anatomy of the middle cerebral artery in various mammal species. The authors of those papers report on the respective 
regions of the brain being supplied by the same arterial branches, which refers to the arteries which occur as single branches in grivet (6), in yellow baboon (7), in European otter (8) and multiple arteries in domestic pig (9).

The pattern of division of the middle cerebral artery is affected by various factors; e.g. the species represented and sulcus pattern of the cerebral cortex. In mammals on the surface of the cortex the sulcus pattern varies, which can affect the anatomy of the cortical branches of the middle cerebral artery (10). Considering the discrepancies resulting from respective descriptions and factoring in new research, it has been decided to investigate the pattern, the division and the variation in cortical branches of the middle cerebral artery in European badger and to compare the results with those reported by other authors.

\section{Materials and methods}

The studies of the middle cerebra artery involved 32 brains in European badger; in total 64 cerebral hemispheres obtained from hunting. Ethics approval was not required since animals died because of natural reasons. The research used the European badger heads cut off at the height of the $3^{\text {rd }}-4^{\text {th }}$ cervical vertebrae. The arteries were filled with latex introduced into common carotid artery with the medical syringe. This method was described by Godynicki (11). Having fixed the heads in $5 \%$ formalin solution and having decalcified the skulls in hydrochloric acid, the skull cavity was opened and the brains were taken out. The cerebral hemispheres were photographed and their anatomy, division and pattern of the cortical branches of the middle cerebral artery were described.

\section{Results}

In European badger the blood is supplied to the brain with internal carotid arteries (Fig. 1a) and vertebral arteries.

The internal carotid artery, having entered the skull and perforated dura mater, bifurcates into the rostral cerebral artery (Fig. 1 b) and caudal communicating artery (Fig. 1c) which, together with the symmetrical vessels form the circle of Willis. From the initial section of the rostral cerebral artery, towards the cortex, there descends the middle cerebral artery.

The middle cerebral artery is the strongest vessel supplying blood to cerebrum. The initial section of the main trunk of the middle cerebral artery heads along the ventral surface of the optic tract and before the rostral border of piriform lobe. Then the section bends around the piriform lobe and goes through its rostral border. Further on it runs to the lateral rhinal sulcus and, having passed it, it gets divided. From the initial section of the main trunk of the middle cerebral artery there descend minor central branches supplying blood to olfactory tracts and the piriform lobe.

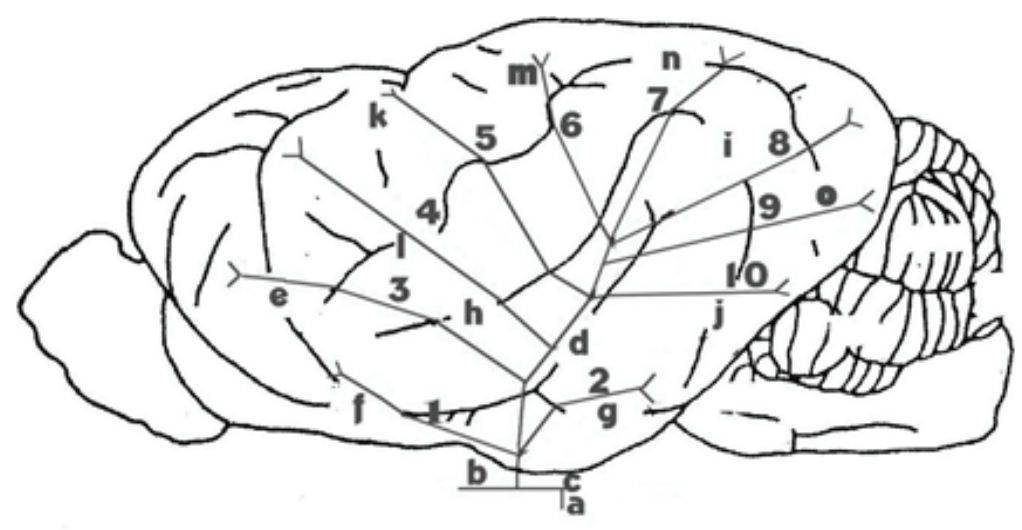

Figure 1: Pattern of division of the middle cerebral artery on the brain cortex in European badger.

1 - rostral olfactory artery, 2 - caudal olfactory artery, 3 - orbital branch, 4 - ventral frontal branch, 5 - dorsal frontal branch, 6 - rostral parietal branch, 7 - caudal parietal branch, 8 - dorsal temporal branch, 9 - middle temporal branch, 10 - ventral temporal branch, a - internal carotid artery, b - rostral cerebral artery, c- caudal communicating artery, d - Sylvian fissure, e - presylvian sulcus, f - rostral lateral rhinal sulcus, g - caudal lateral rhinal sulcus, $\mathrm{h}$ - rostral suprasylvian sulcus, i - middle suprasylvian sulcus, $\mathrm{j}$ - caudal suprasylvian sulcus, $\mathrm{k}$ - cruciate sulcus, 1 - coronary sulcus, $\mathrm{m}$ - ansiform sulcus, $\mathrm{n}$ - marginal sulcus, o - external marginal sulcus 
The main trunk of the middle cerebral artery gets divided further into a number of cortical branches which head for the specific region of the cerebral hemisphere supplying blood to specific regions of the brain. The first permanent branches of the middle cerebral artery which supply blood to both the old and the new cortex are olfactory arteries.

The rostral olfactory artery (Fig. 2-1), having separated from the main trunk of the middle cerebral artery, goes towards the rostral part of the lateral rhinal sulcus it can ascend into in various places. Its terminal branches can also appear again from under the lateral rhinal sulcus and then disappear into the cortex located over that sulcus.

The caudal olfactory artery (Fig. 2 - 2) descends into the caudal part of the lateral rhinal sulcus. Its terminal branches supply blood to the area of the cortex found over that sulcus. The other arterial branches supply the regions of the cortex located over the lateral rhinal sulcus. On the cerebral cortex towards the frontal lobus there spread three thick branches.

The orbital branch (Fig. 2-3) descends first; it runs towards the region of the presylvian sulcus where its terminal branches reach the coronary groove.

The ventral frontal branch (Fig. 2-4) vascularises the middle parts of that region of the cortex. The branch of that vessel goes through the rostral suprasylvian sulcus towards the coronary sulcus.

The dorsal frontal branch (Fig.2-5), having separated from the middle cerebral artery goes up to the regions of the cruciate sulcus. Those vessels supply blood to the upper part of the medial surface of the frontal lobus. The successive vessel which runs towards the parietal lobus bifurcates into two branches.

The rostral parietal branch (Fig. 2-6) runs towards the ansiform sulcus. The terminal twigs of that vessel supply blood to the area of the cortex located behind the ansiform sulcus and run medially of the cerebral hemisphere.

The caudal parietal branch (Fig. 2-7) runs towards the region of the marginal sulcus and it branches out further into minor vessels; some of them ascend to the medial suprasylvian sulcus.

The lateral-caudal surface of the cerebral hemisphere is supplied by the branches of the middle cerebral arteries descending here one by one at various heights and they have been referred to as temporal branches.
The dorsal temporal branch (Fig. 2-8) is usually the most powerful cortical branch of the middle cerebral artery and its further prolongation in the area of the cortex. Having descended from the Sylvian fissure, it goes towards the external marginal sulcus. The branch supplies the upper part of the cortex.

The middle temporal branch (Fig. 2-9) descends a little distance from the previous branch. On the surface of the hemisphere it runs towards the caudal suprasylvian sulcus. Its terminal branches go onto the surface of the occipital lobus.

The ventral temporal branch (Fig. 2-10) goes to the end of the caudal suprasylvian sulcus. Having passed the caudal part of the sulcus, its terminal branches participate in supplying blood to a part of occipital lobus.

Considering the general pattern of the distribution of cortical branches of the middle cerebral artery in European badger presented here, one shall note that the respective sections of those branches can be found inside respective sulci, sometimes undergoing further divisions, always going towards of the cerebral cortex regions described.

Considering the pattern of descend of cortical branches of the middle cerebral artery in the European badger individuals studied, it was found that from the rostral cerebral artery on 60 cerebral hemispheres there descended one independent vessel; the middle cerebral artery. Among them on 15 (23.4\%) hemispheres from the main trunk of the middle cerebral artery there descended rostrally a common trunk for the rostral olfactory artery and for the orbital branch, then a common descent for the ventral and dorsal frontal branches. The main trunk separated the caudal olfactory artery caudally with a common descent from the ventral temporal branch. Having descended into the Sylvian fissure, it brought a common trunk for rostral and caudal parietal branches as well as for the middle and dorsal temporal branches onto the surface of the cortex.

In another $11(17.2 \%)$ cases from the main trunk of the middle cerebral artery there rostrally descended a common descent for rostral olfactory artery and for the orbital, ventral and dorsal frontal branches. Caudally from the main trunk there descended the caudal olfactory artery with a common trunk with ventral and middle temporal branches. The main trunk, having ascended to the Sylvian fissure brought a common descent for 
parietal branches and the dorsal temporal branch onto the surface of the cortex

In yet another $9(14.1 \%)$ cerebral hemispheres the rostral branch was made up by a common trunk for the rostral olfactory artery and the orbital, ventral and caudal frontal branches. The main trunk got onto the surface of the cortex from the Sylvian fissure and created a common descent for parietal branches. Caudally from the main trunk of the middle cerebral artery there separated, with a common trunk, the temporal branches with the caudal olfactory artery.

In $12(18.7 \%)$ cases from the main trunk there rostrally descended an independent rostral olfactory artery, then a common descent for the orbital branch and for ventral and dorsal frontal branches. Caudally, from the main trunk there separated, with a common descent, the middle and ventral temporal branches as well as caudal olfactory artery. The main trunk, having ascended into the Sylvian fissure, brought a common trunk for rostral and caudal parietal branches as well as the dorsal temporal branch onto the surface of the cortex.

On another 13 (20.3\%) hemispheres from the main trunk there rostrally separated the orbital branch, the ventral frontal branch and the rostral olfactory artery with a common trunk. The main trunk of the middle cerebral artery, having appeared on the surface of the cortex, separated a common descent for the dorsal frontal branch as well as rostral and caudal parietal branches. Caudally from the main trunk there separated, with a common descent, ventral, middle and dorsal temporal branches and an independent caudal olfactory artery.

In the other $4(6.3 \%)$ hemispheres it was found that from the rostral cerebral artery there descended two independent branches of the middle cerebral artery. The first independent branch from the rostral cerebral artery was the rostral olfactory artery, while the second branch from the rostral cerebral artery was the main trunk of the middle cerebral artery the orbital branch and frontal branches descended from rostrally with a common descent. The main trunk, having ascended to the Sylvian fissure, brought respectively, the rostral and caudal parietal branches as well as the dorsal temporal branch onto the cortex surface. Caudally from the main trunk there descended independent caudal olfactory artery, ventral and middle temporal branches (Fig. 2).

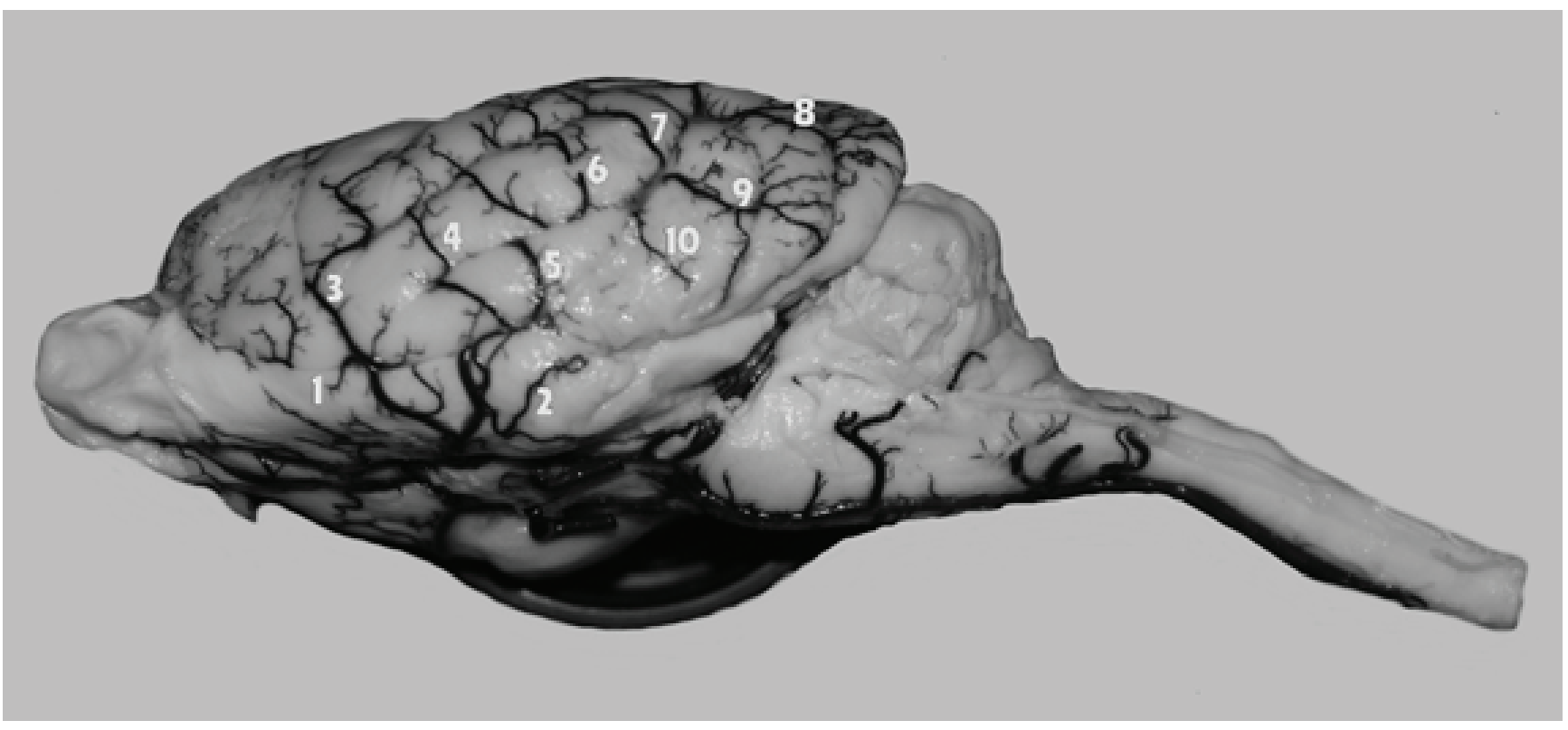

Figure 2: Lateral view of the independent descent of the rostral olfactory artery and the main trunk of the middle artery from the rostral cerebral artery

1 - Rostral olfactory artery, 2 - caudal olfactory artery, 3 - orbital branch, 4 - ventral frontal branch, 5 - dorsal frontal branch, 6 - rostral parietal branch, 7 - caudal parietal branch, 8 - dorsal temporal branch, 9 - middle temporal branch, 10 - ventral temporal branch 


\section{Discussion}

In European badger the middle cerebral artery supplies blood to the same areas of the brain as in the mammal species investigated so far. The discrepancies concern mostly its division into respective branches. Chadzypanagiotis (3), describing the anatomy of the middle cerebral artery in cat, differentiated between the branches supplying the old cortex, the branches on the border of the old and the new cortex as well as the branches for the new cortex. In European badger the arteries supplying blood to the old cortex are minor branches which reach the piriform lobe and olfactory tracts. On the border of the old and the new cortex there run the olfactory arteries: rostral and caudal. In European badger the rostral olfactory artery in $6.3 \%$ of cases was a vessel which descended independently from the rostral cerebral artery. In the other cases it was a vessel which descended independently from the main trunk of the middle cerebral artery in $18.7 \%$ cases and the vessel which got separated with a common trunk with the orbital, ventral and caudal frontal branches.

The caudal olfactory artery, on the other hand, in $20.3 \%$ cases was a vessel descending independently from the main trunk. In the other cerebral hemispheres it was one of the branches of the common trunk for temporal branches or descended directly from the ventral temporal branch.

The other cortical branches of the middle cerebral artery can be divided into a group of frontal, parietal and temporal branches. In European badger, similarly as in European otter and other Carnivora species, there occur eight main vessels which supply blood to the same areas of cerebral hemispheres. Respective cortical branches can descend from the main trunk of the middle cerebral artery with a common descent. Such cases of the decent were reported by Chadzypanagiotis (3), Wiland (4) as the rostral, middle and caudal middle cerebral artery. In European badger the rostral middle cerebral artery has been demonstrated as a common trunk for frontal branches and it occurred in $25.0 \%$ of the cases investigated, the dorsal middle cerebral artery has been referred to as a common trunk for parietal branches was identified in $14.1 \%$ of the cases. The caudal middle cerebral artery as a common trunk for temporal branches was reported in $20.3 \%$ of the cases. In European badger the dorsal middle cerebral artery accounted for the lowest percentage of cases, whereas the rostral middle cerebral artery dominated here. A comparison of the present results with those reported by Skoczylas et al. (8), one can state that also in European otter the dorsal middle cerebral artery accounts for the lowest percentage of cases and the rostral middle cerebral artery - for the highest percentage of cases.

In European badger, similarly as in the mammals investigated, parietal branches are least developed. On the surface of telencephalon the frontal branches of the middle cerebral artery are best developed.

The descriptions of the anatomy of the middle cerebral artery provided in publications of Jabłoński et al. (6), Skoczylas et al. (8) in grivet and European otter show that it is usually a single vessel descending from the rostral cerebral artery. The vessel, having passed the lateral rhinal sulcus, gets divided along its course into respective branches. In the material investigated such a pattern of division of the middle cerebral artery was identified in $93.7 \%$ of the cases. In European badger there were found cases of the descent, from the rostral cerebral artery, two independent arterial trunks in $6.3 \%$ of the cases. The second independent branch from the rostral cerebral artery was the rostral olfactory artery. In the other mammal species the presence of two independent descends of the branches of the middle cerebral artery from the rostral cerebral artery was reported in domestic rabbit in $31.4 \%$ (12) and in raccoon dog (13) w 18,6\% of the cases and in wild rabbit (14) - in $36.5 \%$ of the cases.

The present research shows that in European badger the observed division of the middle cerebral artery into the same branches or their groups as in the other mammal species studied so far is due to genetic limitations. As claimed by Wiland (15), the blood supply to the brain in the individuals of given species the amount of genetic information accumulated over the phylogenetic development can be essential. 


\section{References}

1. Hofmann M. Zur vergleichenden Anatomie der Gehirn und Ruckenmarksarterien der Vertebraten. Z Morphol Anthropol 1900; 2: 247-320.

2. Walinczus J. The middle cerebral artery in domestic pig. Uczen Zap Witebsk Weterinar Inst 1973; 26: 123-7.

3. Chadzypanagiotis D. Arteries on the surface of the cerebral hemisphere in the cat. Folia Morphol Warsz 1975; 32: 385-99.

4. Wiland C. Comparative investigation of cortical branches of middle cerebral artery in some species of Carnivores. Zesz Nauk ATR Bydgoszcz 1991; 44: 1-52.

5. Skoczylas B, Wiland C. Cortical branches of the middle cerebral artery in the wild boar (Sus scrofa L.). Electron J Polish Agric Univ Vet Med 1999; 2(1): e1. http://www.ejpau.media.pl/volume 2 /issue 1/veterinary/art-01.html

6. Jabłoński R, Skoczylas B, Brudnicki W, et al. Cortical branches of the middle cerebral artery in grivet (Cercopithecus aethiops). Prace Kom Nauk Roln Biol BTN Ser B 2005; 56: 51-5.

7. Skoczylas B, Nowicki W, Jabłoński R, et al. Cortical branches of the middle cerebral artery in yellow baboon (Papiocynocephalus Linnaeus 1766). Prace Kom Nauk Roln Biol BTN Ser B 2006; 60: 79-84.
8. Skoczylas B, Brudnicki W, Nowicki W, et al. The cortical branches of the middle cerebral artery in the otter (Lutra lutra). Vet Med 2012; 57(6): 282-6.

9. Skoczylas B. Cortical branches of middle cerebral artery in domestic pig. (Sus scrofaf. domestica). Electron J Polish Agric Univ Vet Med 2000; 3: e1. http://www.ejpau.media.pl/volume3/issue1/veterinary/art-01.html

10. Brauer K, Schaber W. Katalog der sangetiergehirne. Jena : VEB Gustaw Fisher, 1970.

11. Godynicki S. Use of LBS 3060 Latex in anatomic preparations. Folia Morphol Warsz 1971; 30(4): 601-3.

12. Wiland C. Basilar arteries of the brain in the domestic rabbit. Folia Morphol 1968; 27: 288-95.

13. Brudnicki W, Wiland C, Jabłoński R. Basilar arteries of the brain in raccoon dog (Nyctereutes procynoides Grey 1834). Arch Vet Pol 1994; 34: 141-7.

14. Brudnicki W, Nowicki W, Skoczylas B, et al. Arteries of the brain in wild European rabbit Oryctolagus cuniculus (Linnaeus, 1758). Folia Biol 2012; 60(3/4): 189-94.

15. Wiland C. Variability of the brain base arteries in Canidae and Mustelidae. BTN Prace Wydz Nauk Przyr B 1980; 29: 73-95.

\title{
KORTIKALNE VEJE SREDNJE MOŽGANSKE ARTERIJE PRI EVROPSKEM JAZBECU (MELES MELES)
}

\author{
B. Skoczylas, W. Brudnicki, K. Kirkiłło-Stacewicz, W. Nowicki, J. Wach
}

Povzetek: Vzorec in razlike v razvejanosti kortikalnih vej srednje možganske arterije smo preučevali v 64 možganskih poloblah evropskega jazbeca. Ugotovili smo, da se glavna arterija razdeli na deset vedno prisotnih vej. Dve vohalni arteriji oskrbujeta območje možganov, ki se nahaja na meji med področjem neokorteksa in starejšega dela skorje možgan. Preostalih osem vej se deli na triveje, ki se usmerijo v čelno področje, dve veji usmerjeni v parietalno področje in tri senčnične veje, ki oskrbujejo področje neokorteksa. Čelne, parietalne in temporalne veje se spustijo neodvisno od glavnega debla srednje možganske arterije, ali pa najprej oblikujejo skupno deblo. Običajna debla za posamezne skupine vej so opisana kot rostralna, dorzalna in kavdalna srednja možganska arterija. Rostralna vohalna arterija je bila v6,3 odstotkih preiskovanih primerov neodvisna od rostralne možganske arterije.

Ključne besede: arterije; možgani; evropskijazbec 